T. S. Novorodovska, Cand. Sc. (Biol.), Assoc. Prof., orcid.org/0000-0002-4654-843X,

N. P. Korogod, Cand. Sc. (Ped.), Assoc. Prof., orcid.org/0000-0002-0242-5497,

D. O. Tymchenko, orcid.org/0000-0003-2784-883X
National Metallurgical Academy of Ukraine, Dnipro, Ukraine, e-mail: tetiana.novo@gmail.com

\title{
AMERICAN EXPERIENCE OF ESTABLISHING TECHNOLOGY TRANSFER AND ITS IMPLEMENTATION IN UKRAINE
}

Purpose. Generalization of the best practices in technology transfer of American higher education institutions (HEIs) and strategy of their implementation in Ukraine.

Methodology. The study is based on the use of methods of analysis and synthesis, grouping and comparison, systematic analysis.

Findings. The approach to technology transfer of US HEIs is analyzed using the example of the University of Georgia, where the Intellectual Property Policy (IP Policy) is created and implemented, fundamental principles of which are presented in the work. The main problems of promotion in Ukraine of the technologies created on the basis of HEIs, as well as the problems faced by Ukrainian scientists in the field of technology transfer are identified. Suggestions on ways to solve the mentioned problems and establish technology transfer in Ukraine as a whole are made.

Originality. The article suggests creating an IP Policy, a technology transfer office (TTO) with clearly defined functions, the main of which should be studying and revealing the demand in the technology market and their further promotion, developing a web platform for technology tracking and management in each HEI.

Practical value. The findings of this study should be the basis for acquiring skills to perform transfer of the innovative technologies from HEI to business, as well as for further research in this field.

Keywords: Ukrainian HEIs, US HEIs, University of Georgia, technology transfer, intellectual property, startups

Introduction. The problem of transfer of technologies created on the basis of HEIs is the lack of interaction between HEIs and business. Acquiring the skills to promote and transfer innovative technologies from HEI to business will facilitate their demand, help business to be aware of their availability and not to refer to other sources. For Ukrainian HEIs it is possible to adopt and implement the US model of HEIs interaction with business, knowing that protection of intellectual property (hereinafter - IP) is a critical necessity for its commercialization and technology transfer.

Literature review. Ukrainian and foreign scientists and researchers, namely K. Duecker, J. DesRosier, Quentin Thomas, I. Biggs， P. M. Tsibuliov， B. Paduchak，Y. Kapitsa， V. Shovkaliuk and others, have been engaged in scientific research on technology transfer. However, the problems of establishing an efficient technology transfer require detailed study.

Unsolved aspects of the problem. Recently, not only Ukrainian scientists but also scientists from other countries, in particular the USA, who are conducting trainings and willingly share their successful experience, have been paying attention to the problem of technology transfer establishment in Ukraine. So, the issues of implementation of such experience in Ukraine, namely what steps should be taken to establish technology transfer, have not been resolved before.

Purpose. The purpose of this article is to study, generalize and collate the experience in technology transfer of the US HEIs and HEIs of Ukraine, to identify the main problems of establishing technology transfer in Ukraine and suggest ways to solve them, based on the successful experience of one of the most developed countries in the field of technology transfer - the USA.

Methods. Methods of analysis and synthesis, grouping and comparison, as well as systematic analysis, were used during the study.

Results. In the higher education institutions (HEIs) innovative developments, technologies, intellectual property objects (IPO) are created. The implementation of such newly developed advanced technologies by Ukrainian enterprises plays a key role in increasing the competitiveness of both the enterprises and the country's economy as a whole.

(C) Novorodovska T. S., Korogod N. P., Tymchenko D. O., 2020
However, there is a problem of transfer of technologies created on the basis of HEIs, which is the lack of effective interaction between HEIs and business. HEIs do not know how to promote and commercialize their innovative developments, and business is unaware of their availability.

As a result of such a gap, HEIs-based developments are often left unclaimed, and business is forced to contact foreign sources to develop or acquire the necessary technology.

This is why it is very important for the representatives of Ukrainian HEIs to study and implement the successful experience of technology transfer and IP commercialization of HEIs of developed countries.

The Directorate of Innovation and Technology Transfer of the Ministry of Education and Science of Ukraine together with the Biotechnical Initiative of the Ukraine-USA Foundation have organized a training course on technology transfer at the University of Georgia (USA) for the representatives of Ukrainian HEIs. Participation in the event took place on a competitive basis: eight participants, including one of the authors of this article, were selected among 160 applicants from all over the country.

One of the countries where the commercialization of innovative products based on HEI is well established is the USA.

The University of Georgia is one of the best examples of a well-established technology transfer system in the HEI, as it is ranked 1st in the United States in terms of the number of products presented to the market: more than 750 such products according to the data of the Association of University Technology Managers, AUTM. The AUTM includes more than 3000 members working in more than $800 \mathrm{HEIs,}$ research centers, hospitals, enterprises and governmental organizations worldwide [1].

Based on the results of the University of Georgia research, 175 companies and 1300 new jobs have been created. The created companies' annual contribution to the US economy is over US \$ 531 million [2].

Of course, the situation was not always so favorable.

Until 1980, US HEIs had no IP management skills; they were not focused on the commercialization of research findings but were concerned only with publications and grants. In the US, there was no unified government patent policy, and 
government agencies owned all the rights to IPOs, including inventions created in the HEI for public funds. As a result, the state had about 30000 patents, of which only less than $5 \%$ were commercialized.

The turning point for the creation of conditions for the operation of technology transfer in the US HEIs was the adoption of the Bayh-Dole Act (BDA) in 1980.

This document, with subsequent changes and improvements, contains a number of essential provisions, including:

- a unified state patent policy;

- HEIs may own rights to inventions made through public funding;

- HEIs may apply for patents for which they wish to own rights;

- HEIs may dispose the rights to the IP (in particular, transfer under license agreements);

- HEIs have the right to keep funds from licensing;

- after reimbursement for patenting, the remainder of the profits must be shared between the inventors and HEI.

By these provisions with further improvements and additional legislation, the rights and responsibilities of all parties were defined, the conditions and incentives were created for the government, universities, industry and business to engage in technology transfer. This provided a guide for the modern technology transfer specialists.

Based on these uniform provisions, each US HEI established the so-called Intellectual Property Policy (IP Policy).

The preamble to this document of the University of Georgia states that the main mission of the University of Georgia is to acquire and disseminate knowledge, for this purpose the creation of scientific work and new technologies (inventions) with the prospect of further commercialization should be encouraged. This will promote both the professional development of the individual staff involved in the process, as well as the creation of new educational opportunities and the enhancement of the reputation of the HEI as a whole.

Most often, IPOs are created by staff with the use of HEIs' facilities and require legal protection. "IP" means creative and scientific work that has commercial potential and can be protected (inventions, trade secrets, copyrights, trademarks, and others). Therefore, HEI should preserve both the protection of IPOs and the rights of authors and stimulate them for further activities.

For the purpose of establishment of the rights and responsibilities of the HEI and its staff the IP Policy is created and should be acknowledged in writing and recognized by all participants of the process [3].

This IP Policy defines the terms of the IP, the conditions for the distribution of rights to IPOs created on the basis of the $\mathrm{HEI}$, and of the profits from their use.

The revenue from use of IPOs obtained by the HEI from license activity minus the costs incurred by HEI in protecting and licensing the IPOs should be distributed as follows:

- first $\$ 10000$ of accumulated revenue goes to the author in the volume of $100 \%$;

- if revenue is over \$10 000: $25 \%$ goes to the author; $10 \%$ - to the author's research program; $10 \%$ - to the Department/Unit; $15 \%$ - to the HEI's operations; $40 \%$ - to the HEI's research fund [3].

If the IPO is created by a HEI's employee with the use of the HEI's facilities or as an assignment, the rights owner is the HEI, and if it is created by the employee's own efforts, not as an assignment and without use of the HEI's facilities, the rights are owned by the author. When creating an IPO with the sponsorship of a third-party company, organization, entity, and so on, the terms of the distribution of rights should be specified in the agreement with the sponsor, and if there is no agreement, all rights are owned by the HEI.

Before beginning any research, staff should be informed of their rights and responsibilities by project managers.
In their turn, when scientific works and technologies that have commercial potential are created, the authors are obliged to inform the HEI about this and to cooperate and contribute to their further commercialization and legal protection.

If the HEI's staff requires cooperation with third-party organizations or individuals to create an IPO, the HEI should be informed in advance to determine the further distribution of rights and profits.

The HEI should evaluate IPOs developed in the HEI and determine the prospects for the registration of rights and further commercialization. Whenever the HEI chooses not to administer an IPO it may be assigned to the author [3]

So, first of all, like in the US HEIs, the IP Policy which is compulsory for the implementation must be created in every HEI in Ukraine. In this policy special attention should be paid to technology transfer. Here are the features of this process.

As stated above in the IP Policy of the University of Georgia, the main mission of the HEI is to acquire new knowledge and to transfer both old and new knowledge. The knowledge transfer of the HEI can be done by:

- teaching (undergraduate, graduate/professional, postgraduate, and so on);

- research (including publications, joint research with other HEIs, research institutions, and others);

- IP license agreements [4]

Technology transfer is promotion of the mission of the university through transfer (including through licensing) of university-owned IP rights to outside entities, usually for compensation [4].

World intellectual property organization (WIPO) defines technology transfer as "a process that bridges between science and industry, and that enables the marketing of goods based on academic research" [5].

A license is a business arrangement in which a university gives a company permission to manufacture and sell its product for a specified payment [4].

Property rights mean both tangible and IP rights [4].

IP rights of the HEI are generally the result of scientific research, most of which, at least in the United States, is sponsored.

According to AUTM statistics for 2017, the distribution of research funding in the US HEIs is as follows:

- state: $58.5 \%$ (67.6\% in 1980);

- enterprises: $7.0 \%$ (3.9\% in 1980);

- others: $34.5 \%$ (foundations, local government, university foundations, private contributions) [6].

For comparison, in Ukraine the research funding of HEIs is distributed between sources as follows [7]:

- the state: $71 \%$

- enterprises: $13.5 \%$;

- others: $15.5 \%$ (foreign sources, own funds, non-profit organizations, funds from other sources).

Thus, in Ukraine, almost the only source of funding for research is the state one, HEIs do not know how to or cannot attract business attention to their development and research, and business, in turn, shows little or no interest in HEIs' technologies/inventions.

At the same time, the indicator of financing of scientific activity by business in Ukraine of $13.5 \%$ is not comparable to such indicator of $7.0 \%$ for the US HEIs, because if these indicators are compared in terms of the monetary value, financing in the USA is several times higher than in Ukraine.

For comparison, in 2017 the funding of research in the US only by state amounted to $\$ 511$ billion, while the total amount of such funding in Ukraine amounted to $\$ 478$ million [8]. Thus, in the USA, amount of funding research is more than 1000 times bigger than this for Ukraine.

That is why the current condition of HEIs in Ukraine can be compared to that of the US HEIs before 1980, when the US HEIs were not focused on the commercialization of research results and were focused only on publications and grants. 
What is the strategy for changing this condition of HEIs? The strategy of setting up a HEI to commercialize its own research results and developed technologies is complicated, but it is realistic as the US experience demonstrates.

In addition to the creation of IP policy in each HEI of Ukraine, as noted above, that would include the IP definitions, terms of distribution of rights and profits in relation to the IPO developed in a HEI, it is also necessary to realize that the main source of the IPO involves the researchers, authors of research and inventions.

Results of their scientific, technical and creative activities, such as new technologies (inventions) in various fields of human activity, can be used in any way in economic activity.

In this context, for Ukrainian scientists the main problems are:

- low salaries (ten times smaller than those of colleagues from European countries or the USA);

- some advanced projects cannot be implemented because even the maximum amount of the state grant does not cover the necessary initial costs for its implementation;

- if the research is carried out by a teacher (professor, associate professor), he/she has additional responsibilities, including 600 hours of teaching activities, scientific, methodical and organizational work.

In the framework of these responsibilities, he/she has less time to carry out research activities, and the additional time spent on research is not paid. In this case, teachers should either work part-time as research assistants or involve other mechanisms (state budget themes, and others).

For comparison, an American professor has the main responsibility - scientific and research activities. Professors who are only teaching receive a lower salary, which motivates them to engage in research. At the same time, an American professor has sufficient "academic freedom". "Academic freedom" means "... the right to freely choose the directions and methodology of one's own scientific pursuits, including contradictory or unpopular views, to raise any problems, to carry out a wide approbation of scientific results obtained" [9].

Unlike in Ukraine, methodical and organizational work is not regulated, that provides a professor with the opportunity to determine the time to do research independently.

When hired, US professors also receive a start-up capital sufficient to purchase the necessary research equipment.

However, they are in a competitive environment and one of the most important criteria for evaluating a particular professor's work is the amount of funds involved in the HEI. It also promotes healthy competition and enhances the level of research projects.

Therefore, the salaries of teachers who are additionally engaged in research activities should be higher than those of teachers who are only engaged in the teaching process. Such teachers should have more academic freedom, and the total funding for HEIs and academic institutions should be several times higher. Thus, for any positive changes the Government of Ukraine should revisit the research development strategy and reasonably increase the funding, emphasizing the value of the technologies developed in HEIs and the necessity of their effective promotion.

After all, in most domestic HEIs technologies are created on the basis of economic and contractual relations. For example, representatives of a HEI contact the profile companies with the proposal to purchase already created technology or to create the necessary technology (IPO, invention) for the enterprise. In the best case, if the enterprise agrees to buy a technology or invest in its creation, the HEI receives the funds, but in most cases, the enterprise becomes the owner of this technology. The HEI does not invest in its patenting, which would allow the rights to the technology to be used in a completely different way, namely, to transfer the rights to its use according to license agreement receiving royalty from the profit (permanent long-term profit payments).
On the other hand, often the inventor creates the invention in the process of his/her research activities, invests in its patenting, but such invention remains non-demanded. This may be due to the fact that he/she has not previously studied the market demand, or to the fact that he/she is not able to promote his/her invention, in particular, he/she does not know the channels and tools, which is quite logical, because the inventor is usually a scientist, a developer, and not a manager, marketer or business strategist.

By way of comparison, to solve the above-mentioned problems in the US HEIs technology transfer departments (offices) are created. In Ukraine not all HEIs have such departments. Technology transfer office (TTO) or the office of IP management is a structural unit of a scientific organization focused on integrated and systematic management of research results, from the planning and creation of IP rights objects to commercialization of the latter and entry into business, mainly in the form of license agreements and/or making startup companies [10].

TTO managers are exploring the technology market demand. They search for companies potentially interested in technologies to further collaborate on technology creation or transfer right to use already created technology.

With regard to HEIs, as stated in the IP Policy at the University of Georgia, authors of newly developed technologies are obliged to inform the HEI about their creation. For example, the University of Georgia uses a special web platform Sophia (Figure) [11], which is a convenient form that is filed by the technology author (abstract, information about authors, publications, funding), the data is further analyzed by a technology transfer manager.

As a result, prospects for patenting of an invention and its commercialization are evaluated, and a strategy is developed. After rights registration and technology transfer, the program monitors the distribution of funds and subsequent stages of work. Similar to the US, Ukraine's HEIs require to develop a similar filing forms for easy tracking and management of HEIs technologies. An online source (database) was created for each US HEI where all of its technologies (inventions) are available.

There are also similar databases in Ukraine that accumulate technologies developed by various HEIs (National Technology Transfer Network http://www.nttn.org.ua/; The Science and Technology Center in Ukraine http://www.stcu.int/, and others). However, the current experience shows that the target audience for the acquisition of these technologies, namely business, is not aware of the existence of such databases and business representatives or investors do not use such sources on their own.

As for the latter, for example, when asked about the usefulness of such platforms, the technology transfer manager of the University of Georgia answered that, indeed, such databases are not considered as a channel for promoting the HEI's technologies, the business does not search on its own and is not aware of the availability of such databases, but they should exist at every HEI as their absence may indicate the absence of innovative technologies in the HEI worth commercializing.

The problem of promoting HEI's technologies in Ukraine is also that they are presented mainly at scientific conferences and in publications that are not related to business. Business cannot find out information about them through such channels. Therefore, it is necessary to be aware of the events and activities that will involve not only HEIs and research organizations representatives but also business (potential investors or technology buyers). In the USA, HEIs often arrange such business-oriented activities. In addition, in the USA the social networks (linkedin, facebook, instagram, etc.) are actively used for promoting technologies. Also, information about the HEI's technologies is provided to enterprises for persons responsible for technology implementation and contracting, namely, business development, strategy development and 

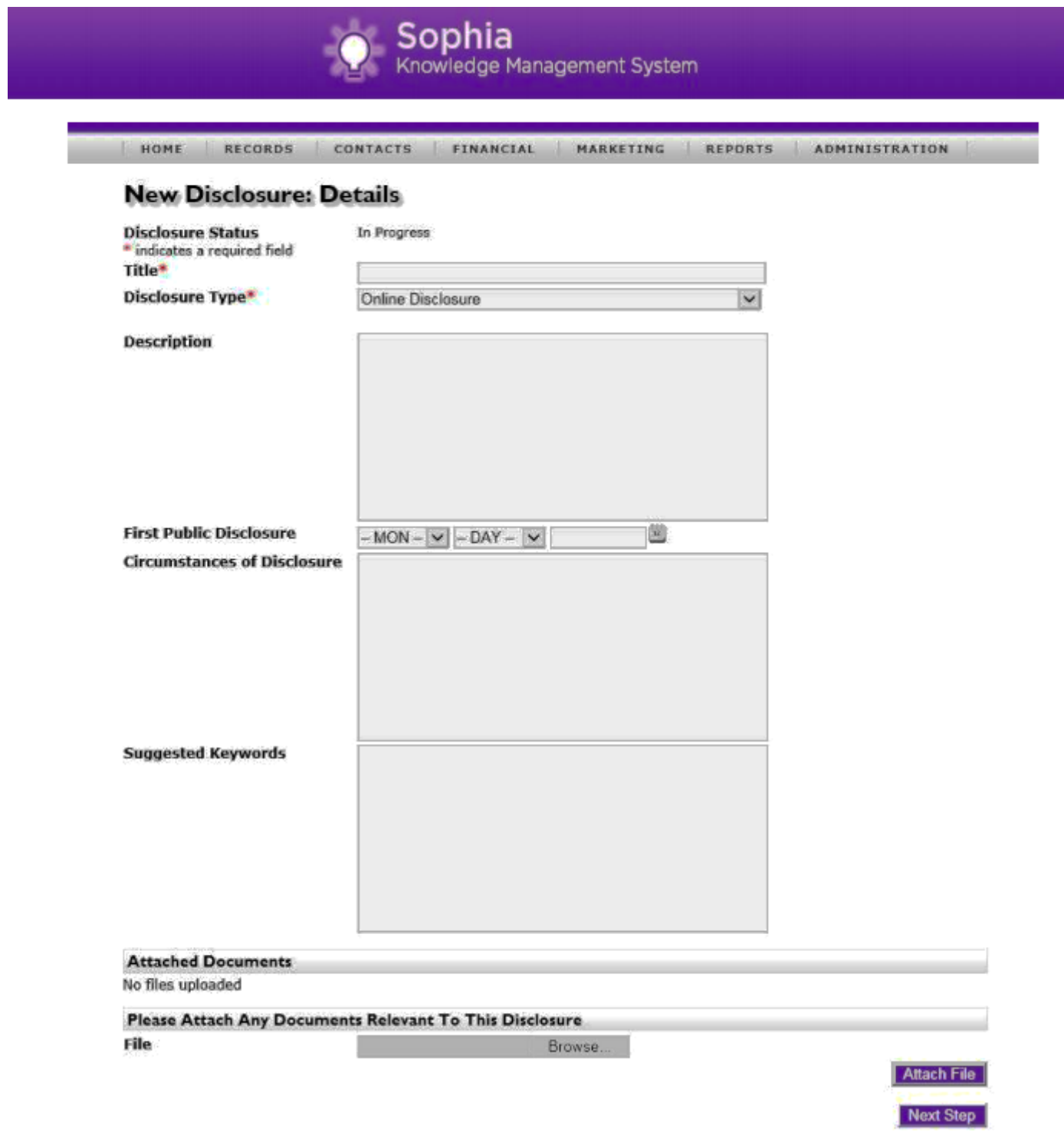

Fig. Online disclosure screenshot of web platform Sophia

R\&D managers, IP specialists, and, of course, directors, founders and so on [12].

The main functions of technology transfer departments are presented in Table.

It should be noted that the US HEIs have now shifted their focus vector from large companies and corporations to startups based on any innovative technology [13].

Why startups? Because large companies (like most investors) prefer not to risk investing in the early stage projects of the HEI (exactly when the investments are most needed) and prefer to invest in already created and tested technologies [4].

Startups are ready to take on such risks. Since startups are new companies that bring innovative technologies to the field, the US HEIs are directly contributing to their creation, because researchers are aware of entrepreneurial activity as its included in educational programs (by the way, this subject is completely absent in technological HEIs of Ukraine and researchers are not at all aware of entrepreneurial activity) and have the desire to start their own business with the use of promising technologies just developed in HEIs.

In order to support innovative projects, there are internal funds in the HEIs, and there are competitions for such projects with monetary incentives. A HEI gives startups the right to use these technologies through a license agreement, and often provides favorable conditions for the operation of such startups - for example, room for low price, equipment rental and others. Interestingly, the cost of using rooms and equipment is increasing for such companies every year - in such a way, the HEI prevents these companies from getting stuck in development and gives way to new startups [14].

As a result of such a mutually beneficial collaboration between a HEI and a startup, the startup grows faster, makes profit, and the HEI receives royalties from profits under a license agreement.

This model of interaction should also be adopted by Ukrainian HEIs and startups.

Conclusions. In conclusion, we can confidently recommend that the US HEIs' successful experience in the field of IP and technology transfer should be adopted and implemented in Ukrainian HEIs.

Strategy for its implementation could include the following steps and improvements:

1. Like in the US HEIs, in every HEI in Ukraine the IP Policy must be created being compulsory for the implementation; the policy defines the terms of the IP, the conditions for the distribution of rights to IPOs created on the basis of the HEI, and of the profits from their use. In this policy special attention should be paid to technology transfer. However, we should start with the harmonization of the legislative framework at the national level, which now has significant gaps, since the IP policy of HEIs must comply with the applicable legal acts. 
The main functions of TTOs

\begin{tabular}{|c|c|c|}
\hline n. & Function & Tasks \\
\hline 1 & $\begin{array}{l}\text { Market research to reveal } \\
\text { demand for innovative } \\
\text { products/technologies }\end{array}$ & $\begin{array}{l}\text { - avoiding of wasting time and money of scientists for developing technologies; } \\
\text { - prevention of the lack of demand for developed technologies; } \\
\text { - search for companies potentially interested in technologies that are specific to the HEI; } \\
\text { - organization of meetings and negotiations, which involve representatives of enterprises, technology } \\
\text { transfer managers (mediators) and researchers of the HEI; } \\
\text { - explanation of the essence of technology created at the HEI in a language understandable for business } \\
\text { that differs from the scientific language of the developers }\end{array}$ \\
\hline 2 & $\begin{array}{l}\text { Studying innovative } \\
\text { technologies developed in the } \\
\text { HEI, estimation of cost and } \\
\text { expediency and prospects of } \\
\text { patenting }\end{array}$ & $\begin{array}{l}\text { - creation and use of a special web-platform, which is a convenient form filed by an author regarding the } \\
\text { developed technology (abstract, information about authors, publications, funding); } \\
\text { - the data is further analyzed by a technology transfer manager; } \\
\text { - the prospects for patenting and commercialization of the technology are evaluated, a strategy is being } \\
\text { developed; } \\
\text { - after rights registration and technology transfer, the program monitors the distribution of funds and } \\
\text { subsequent record keeping }\end{array}$ \\
\hline 3 & $\begin{array}{l}\text { Creating a database of all the } \\
\text { HEI's technologies }\end{array}$ & $\begin{array}{l}\text { - to create an on-line resource (database) for each HEI, where all the HEI's technologies are outlined; } \\
\text { - to create all-Ukrainian resources, which accumulate technologies developed by various HEIs (for } \\
\text { example, as the National Technology Transfer Network, The Science and Technology Center in Ukraine); } \\
\text { - to inform business and potential investors about the availability of such databases }\end{array}$ \\
\hline 4 & $\begin{array}{l}\text { Monitoring of events (markets } \\
\text { and festivals of innovations, } \\
\text { conferences, etc.) }\end{array}$ & $\begin{array}{l}\text { - presenting developed technology not only at scientific conferences and in publications, but especially } \\
\text { at the events involving representatives of HEIs and research organizations as well as businesses (potential } \\
\text { investors or technology purchasers) }\end{array}$ \\
\hline 5 & $\begin{array}{l}\text { Search for online channels for } \\
\text { technologies promotion }\end{array}$ & $\begin{array}{l}\text { - using social networks (linkedin, facebook, instagram, etc.) actively; } \\
\text { - sending a short description of the developed technologies in the letters to the profile companies, which } \\
\text { may have a potential interest in their implementation; } \\
\text { - posting relevant information on various blogs, videos and more }\end{array}$ \\
\hline 6 & Licensing & - to conclude license agreements and monitor the royalty payments \\
\hline
\end{tabular}

2. Teachers who are additionally engaged in research activities should have a higher salary than those teachers who are only engaged in the teaching process. Such teachers should also have more academic freedom, and the total funding for HEIs and academic institutions should be several times higher.

3. The state should focus on introducing effective technology transfer management including: providing HEIs with the necessary equipment to conduct research and create innovative technologies, organize activities to facilitate the cooperation between HEIs and business representatives, create a system of incentives for such cooperation, initiate training for technology transfer specialists, disseminate IP and technology transfer to a wide range of people.

4. Like in the US HEIs, in all Ukrainian HEIs technology transfer departments (offices) should be created. The main functions of TTOs should be market research to reveal demand for innovative products/technologies, studies on innovative technologies developed in the HEI, estimation of cost and expediency and prospects of patenting, creating a database of all the HEI's technologies, monitoring of events (markets and festivals of innovations, conferences, and others), search for online channels for technologies promotion, patenting, licensing.

5. Similar to the US, Ukraine's HEIs require to develop easy-to-use filing forms for tracking and management of HEIs' technologies and create an online source (database) where all of the technologies (inventions) developed at the HEI are available, with the possibility of further merging the databases of an individual HEI into an all-Ukrainian database.

6. In all Ukrainian HEIs researchers should be aware of entrepreneurial activity (this course should be included in curricula, for example).

7. HEIs should enter into close collaboration with the startups to receive mutual benefits: the startups grow faster, make profits and the HEI receives royalties from these profits under licensing agreements.

After all, HEIs should clearly recognize that the protection of IP is a critical necessity for its commercialization.
Since the development of an innovative product requires considerable investment of time and resources, in order for an enterprise to invest in these developments, it must be assured that the exclusive rights for their further use will belong to it.

In today's environment, more and more often the IP becomes the most valuable asset for companies.

Further development of research in this area is extremely important.

The project, within which the results were presented. A training course on technology transfer at the University of Georgia (USA) was organized for the representatives of the Ukrainian HEIs, including the co-author of the article.

Acknowledgment:

John P. DesRosier, PhD.

Rusty Brooks, PhD.

Cristina Redko.

Biotechnical Initiative of the Ukraine-USA Foundation.

The Directorate of Innovation and Technology Transfer of the Ministry of Education and Science of Ukraine.

\section{References.}

1. About AUTM: Who We Are. (n.d.). Retrieved from https:// autm.net/about-autm/who-we-are.

2. Terrazas, M. (2019, January 11). UGA ranks No. 1 in U.S. for new products to market. UGA Today. Retrieved from https://news.uga.edu/uga-ranks-no-1-products-market/.

3. IP Policy of the University of Georgia. (n.d.). Retrieved from https://research.uga.edu/documents/intellectual-property/.

4. DesRosier, J. (2019). Technology Transfer Basics: Programs and Practices in U.S. Universities [PowerPoint presentation]. Retrieved from https://drive.google.com/file/d/1S3 XVNQuhHfbhuAZLxYhRLzyCj7cx 2Ll.

5. Technology transfer in countries in transition: policy and recommendations division for certain countries in Europe and Asia (2012). WIPO, p. 64. Retrieved from https://www.wipo. int/edocs/pubdocs/en/wipo pub transition 2 b.pdf. 6. Hockstad, D., Mahurin, R., Miner, J., Porter, K.W., Robertson, R., \& Savatski, L. (Eds.) (2017). AUTM US Licensing 
Activity Survey. Retrieved from https:// autm.net/AUTM/media/SurveyReportsPDF/AUTM_2017_Canada_Licensing Survey without Appendix.pdf.

7. Scientific and innovative activity of Ukraine: statistical compendium of State Statistics Service of Ukraine (2018). Kyiv. Retrieved from http://www.ukrstat.gov.ua/druk/publicat/kat_u/2018/ zb/09/zb_nauka_2017.pdf.

8. The Global Innovation Index 2019 (2019). Retrieved from https://www.wipo.int/edocs/pubdocs/en/wipo_pub gii_2019-chapter1.pdf.

9. Academic freedom. Electronic version of the Great Ukrainian Encyclopedia (n.d.). Retrieved from https://vue.gov.ua/ Академічна свобода.

10. Tsybulov, P. M., \& Chebotarov, V. P. (2016). Office of intellectual property management: creation, work, efficiency. Tutorial. Kyiv: UkrINTEI. Retrieved from http://www.library. univ.kiev.ua/ukr/elcat/new/detail.php3?doc id=1706721.

11. Applications (Sophia platform) (n.d.). Retrieved from https://signon.ovpr.uga.edu/.

12. Quentin, T. (2019). Emory University Office of technology transfer: technology marketing [PowerPoint presentation]. Retrieved from https://drive.google.com/ file/d/1S3rKjehL1OQUh-d2gyFEfngpWJzBY Sq/.

13. Chmyr, O. S. (2016). Review of scientific approaches to defining the essence and models of innovation activity. Kyiv: UkrINTEI.

14. Biggs, I. (2019). University Startups [PowerPoint presentation]. Retrieved from https://drive.google.com/file/d/1Me 9vnXJeOo36200JGbJPxsfXGis0L0wL/.

\section{Американський досвід у налагодженні трансферу технологій та його імплементація в Україні}

\section{Т. С. Новородовська, Н. П. Корогод, Д. О. Тимченко}

Національна металургійна академія України, м. Дніпро, Україна, e-mail: tetiana.novo@gmail.com

Мета. Узагальнення передового досвіду американських закладів вищої освіти (3ВО) у сфері трансферу технологій і стратегія його імплементації в Україні.

Методика. Проведене дослідження грунтується на використанні методів аналізу й синтезу, групування та співставлення, а також системного аналізу.

Результати. Проаналізовано підхід до питань трансферу технологій ЗВО США на прикладі Університету Джорджії, де вироблена й запроваджена Політика інтелектуальної власності (Політика IB), основні положення якої наведено в даній роботі. Визначені основні проблеми просування розробок в Україні, створених на базі 3ВО, а також проблеми, з якими стикаються українські вчені у сфері трансферу технологій. Надані пропозиції щодо шляхів вирішення визначених проблем і налагодження трансферу технологій в Україні в цілому.

Наукова новизна. Полягає в тому, шо в кожному 3ВО запропоновано введення Політики IB, створення офісу трансферу технологій (ОТТ) із чітко визначеними функціями, основні з яких - вивчення й виявлення попиту на ринку технологій та їх подальше просування, розроблення web-платформи для відстеження й менеджменту технологій.

Практична значимість. Висновки даного дослідження можуть бути основою для набуття вмінь здійснювати трансфер інноваційних розробок від ЗВО до бізнесу, а також для подальших досліджень у цій галузі.

Ключові слова: українські ЗВО, ЗВО США, Університет Джорджії, трансфер технологій, інтелектуальна власність, стартапи

\section{Американский опыт в налаживании трансфера технологий и его имплементация в Украине}

\section{Т. С. Новородовская, Н. П. Корогод, Д. А. Тимченко}

Национальная металлургическая академия Украины, г. Днепр, Украина, e-mail: tetiana.novo@gmail.com

Цель. Обобщение передового опыта американских высших учебных заведений (ВУЗ) в сфере трансфера технологий и стратегия его имплементации в Украине.

Методика. Проведенное исследование основывается на использовании методов анализа и синтеза, группировки и сопоставления, а также системного анализа

Результаты. Проанализирован подход к вопросам трансфера технологий ВУЗ США на примере Университета Джорджии, где создана и внедрена Политика интеллектуальной собственности (Политика ИС), основные положения которой приведены в данной работе. Обозначены основные проблемы продвижения разработок в Украине, созданных на базе ВУЗ, а также проблемы, с которыми сталкиваются украинские ученые в сфере трансфера технологий. Даны предложения относительно путей решения обозначенных проблем и налаживания трансфера технологий в Украине в целом.

Научная новизна. Заключается в том, что в каждом ВУЗе предложено введение Политики ИС, создание офиса трансфера технологий (ОТТ) с четко определенными функциями, основные из которых - изучение и выявление спроса на рынке технологий и их дальнейшее продвижение, разработка web-платформы для отслеживания и менеджмента технологий.

Практическая значимость. Выводы данного исследования могут быть основой для приобретения умений осуществлять трансфер инновационных разработок от ВУЗ бизнесу, а также для дальнейших исследований в этой отрасли.

Ключевые слова: украинские ВУЗ, ВУЗ США, Университет Джорджии, трансфер технологий, интеллектуальная собственность, стартапы

Recommended for publication by V. H. Marhasova, Doctor of Economic Sciences. The manuscript was submitted 28.12.19. 